$\overline{\text { 說苑 }}$

\title{
アメリカの纖維だより
}

会員友成九十九

丁度 1 ケ月になります。夢のようにこの1ケ月を過ご しました。相当な收檴です。来てみねばわからぬことが 沢山あります。しかしわかるほど解決の困蜼な問題、彼 我の䣄隔が大きいためどのようにしてこの䀣隔を縮ぢめ るかの問題に出食わして、はたと当惑してしまいます。 10年おくれているとか20年だとかの問題ではない。表面 的にあらわれたその差で云々するのでは到底解決できま せん。例えばこの Massacbusetts mstitute \& Techunology. は70年前につくられたのですが、これだけのるの があつて米国の繊維工業の基礎がつくられたのを思えば 日本では横浜の繊維試験所以外各社の研究所各大学の研 究㸟設を見て殆んどないというてもよい位の貧弱な研究 施設です。この有様で纎維工業の発展など期待してよい あの心どうかさ方疑われます。この M. I. T. で1年 に $20,000,000 \sim 30,000,000$ 弗(邦価換算 7 億2000万円) の金を使つて研究している。 M.I.T. 亿類する Texlile Rlsarch Instituton は米国内に10 以上女るので Textile Research †゙けです米国では少なくす約 10,000,000 (36 億门) の金を使つていると考劣てみて下さい。日本で何 がだきるかと自づからを疑いたくなる。研究の上に立つ て工業の発展を考之ている国では大分物の考方方が違つ ている。合成繊維などでも落葀いた物の考え方をしてい る。例えば研究が出来て工業化の準備が出来てす、少く とも $30,000,000$ の金がなければ手が出せぬと考えて。 誰もかれるが合成繊維に手を出すようなことはない。 dv pont の仕專には皆頭を下げて羡やましいか子知れ奴 が、その真似は出来妨。いらいらしてつまらぬるのに手 を出しては大変价という考えで、見方によつては消極的 な考えを述べる人すある。 Nylon，Onlon，Fiber V (Teryleve) は dupont に独占され、Saran は Dow に 独占されてこれからどの繊維をはじめたらよいのか、 Carbide \& Carbon が demyl をやろろとしているが思 い切りがつか奴。Monsant 及び Aruerican Viscose の chemstrand もまだ熱成中だ、devyl や cbemstrand は Orlon K似たところがあつて、dupont の Orlon にど れだけ対抗できるかまだ賕わしい、 chemstrand は染色 性の改善をかかげてみたがその改善がぞれだけ市場で高 く評価されるぶ㐫哮てみねばならぬ。そこに Vinylon が持ち込された Nylon, Orlon などと違つた
性質をるつという吸湿性があり、染色性がすぐれている そうだ。なるほど O H基をるつているのだからこの $\mathrm{OH}$ 基に化学的变化を與えればいろいろ違つた性質のものが 得られるだろ万。耐水性は充分だといらが、更によくす る方法があるだろう。紡系の前にOH基を多少ふさいて 紡糸したら年つた緯ができやしないかなど興味める問 題が思い浮んでくる。Nylon や Orlon のよいところと わるいところとがわかつた專門家が Vinylon を改めて 研究しようという機運が出来て来ました。1948年 5 月. Vinylon という名前をつけて世界に紹介したこの名前も 今では一部の人々には familiar の名前となつて来まし た。これからは世界の学者や技術家が研究して品質改 善、コスト切下げの手助をしてくれるようになるでしよ 弓。 polyvinyl alcohol 系の繊維が 1927 年頃独兔の Dr. O. Herrman にようてつくられた。耐水性改善のために 各国で研究がすすめられた。そして日本で1940年頃に桜 田君、季君、矢沢君などが研究を一歩進めてこの瀻維の 耐水性改善に光明を與光、日本の学者や技術家がその後 更に研究をつづけ、倉教が卒先し大企業化を推進してい る、このことはこちらの專門家はよく知つています。 Nylon や Orlon Saran などのようにこの Vinylon が 1 ケ所で研究され且独占されるようなるのではなく、ど こであやれるところにこの Vinylon の特色がある。た 方日本でこれまでやつて来たのだから、日本の関係者が 協力して、日本で 1 歩も2 歩す前進して他の追從を許さ

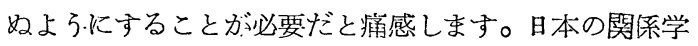
者や技術者は大乗的に物を考六ねばなりません。これを あたか子自分 1 人で物炕するらな考えでは折角のこれ までの努力が無䭾になると思います。私の出発前の悩み はそこにあつたのですが此片に来てますますその考えを 梁くしました。Vinylon は既厄世界の人々の注視の中 close up して来ている new fihe です、他国人の笑い

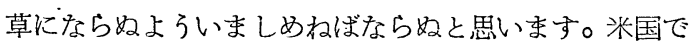
見学した M. I. T, Philadelphia, Princeton, marcas Hook, Porton その他の Textile Research をみて如何 に fasic rsearch に重点を挌いているか。これらの Instituti の人々から質問される Vinylon の basic, reserch, 例えば重合度、アセタール結合様式、加水分解 染色機構 $\mathrm{OH}$ 相互の結合状態などの定性的、定量的研究 
かをだまだ不十分なのを残念に思つています。重合度、 強伸度、弾性性質、その他の性質、式験江高周波、畐波、 電気的方法を危用して、随分進歩した研究方法を抔用し ている。これらの研究施設か日本につくられるまで、私 は米国の研究者の協力を得て Vinylon 研究を進めたい と考えて計画をたてています。皆様によろしく。

\section{(註 記)}

以上の友成博士の便りの中に尠くも次の大きな示唆を 吾々は與えられ委す。

1. 研究費のオーダーカ違了。

日本でも最近やつと䋐維研究に対する態度力㣀剣にな

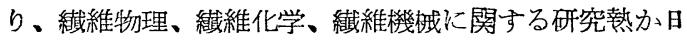
と共に高末つてはいますか、その程度はまるで米国とは 比較になりません。纎維機峨学会力華々しく活動してい る、䋊維学会も沢山原稿は集まりつつある、高分子化学 拹会は勿論、日本化学会、物理学会、機峨学会、応用力子 学会、電気学会等も繊維研究を始めてはいますか何れす 研究費は皆無に近い現状てす、民間会社でも東伴紡、鐘䄱 東佯レーヨン、倉教レーヨン、大日本セルロイド、帝国 繊維、帝人、国策パルプ等は大部研究に熱のある会社で すか、何れも研究費年 1 億门には遥かに及はない現洗て す。头国の效10億円の研究費とはするでオーダーか違い ます。月本て研究をやつている所もあまりやら呚と、 他の会社とつ振合いかとれ如、株主かろるさい、会社の 幹部か何をしているかもたたかれそうた、位のところか ら、装面的に扮茶をニゴ程度の研究をしている現况で す、研究を基整にして、企業を興し、会社む大いに利益 を得て、社会もこれから大きな思恵に浴せるのだという 米国の場合とはまるて違います、米国ては研究を基礎に して、充分な企業か出来上り、会社は隆々として大きな 利益を学行、從業員、株主は勿論、一般社会もこれから 大きな文化の恩击に谷せることか今まての各理の研究に よつて続々と垁証されているから、国家子会社す、人民 す安心して、空万先を争つて研究費を出している。所か 日本てはまだそれだけの興論の支持を受ける研究力尠 い、たから、研究は企業のつけたりであり、カンバンで 岕る。会社の重役にして子研究は一喠の直楽でる位に しか考穴て批らず、研究者自体も学位論文の资料にする ことは真剣に考えていてあ真に会仕の経営に直接影響す る大きな開題には経槄的な感覚かニフイせいか比較的冷 淡てある。たからつい企業か主て研究か從になる、米国 の如く研究力主て企業力從になるのとは大部に違了。日 木の大学に括る研究も残念なから大同小異である、企 業の実体を知らぬ大学の先生片かドンキホーテになる、 或は立版な実力や業績を持つていても会社経営の実態を

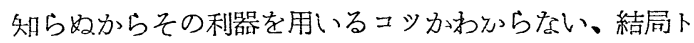
ンキホーテになつて会社にらるさかられるか、㕛は象牙

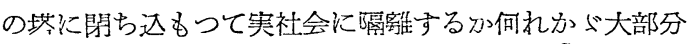
の姿だ、たわら今の所会社の研究者にしても天学の教官 迶中にしても研究費か涞国の邱究費とは比較にならぬの も無理はない。研究費のオーダーか日本と米国と比較に ならぬのを会社重役萑会は充分に認瀧すると共に研究者
としては自分の研究か证業に先行し得るか、或は宇宙交 化にぞれたけ筒與し得る力を充分に反省しなからその研 究費の多察を云々すべきであろ。

2. 基礎的研究力行き届いている。

基礎的研究は湯川博士の扣かけで日本です度々論箪さ れ、議会ですよく問題になつているか、日本では依然と して極めて低調てある、この根本には一般人に科学的素 荃力教養されて打らず、基礎的研究の有䧼味か一般に理 解されないのにるよる。早い話かりロバンは一般に役に 立つとは認められているか、高等放学は学校を出るすで のことて、出てしまえはあまり必要を感しないというの か一般の論誡である、日本に基礎的研究を米国程に振與 させるためには先つ、小学校から教育の反省を加えて、 基礎的事項か、とんなに人類社会の文化に影響を與える か、今一度交化の尺度を考光直ほして見る必要かあろう。

3. 協同研究、又は研究関する拹力か徹底している。

日木の学者はとらも㹨量なのか多い、会社の研究者て る同样である、岕る人か相当な研究を発表するといつま でも自分の功績としてとつて扣きたいのかその研究に自 分の研究室以外の人逆か，参加するのを好末妖か多い し、又他の研究者る、自分力潒の下の力持ちになつて他 人の研究を完成するために欣然参加すること力比較的尠 ない、そいうことか大きな研究を完成する障睨をなし ている。湯川博士かユーコンを発表してる、日本か百子 爆弾を作れるとか作れないとか議論をしている中に、米 国ては早速これをとり上けて数千人すの人達かこの研究 に参加して、立ちところに原子暴弾を完成して第 2 次大 戦を終昰に道いたはかりてなく、更に水素暴弾へと発展 して、第 3 次大戦の防畋としている外、各喠の原子医動 機械に展開して次々に人類交化に笴與する方向に進んて いる。

ビニロン、アミラン、エストロン等にしても同様て、 これを始めた研究者は真剣にその效用を説き、企澲化を 開始した会社は鋭意その完成に尽度しているか、乗り拉 くれた会社や一般人はいいとか要いとかろくによくも解 らないのに不用意な批判を繰返している中に、友戍印の 来信の如く米国かこれを取上けて大規㷬な研究協同によ つて一学隹萻化を完成しかねましき有様てある。当分 の間繊維工業によるの他生きる道のない日本か、平和の スポーツ、繊維工業技術に颃いても、原暴同样、トとに めぶらげをさらわれようとしている。

湯川氏は今米国て世紀の英雄として華々しい歓待をう けているか、その協同研究に参加せずその企業化に成功 しなかつた日本国民は伝然㹨まい四つの島に敗戦国民の 浮き目を味わつている。緸維人は勿論、化学者、物理字

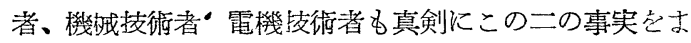
ともに見なけれはならないてしょう。

等々読む人の心に上つて映る候は違つて来るか、重も 角この手紙をじつと自分の机の中汸に納い込んて扎く のに忍ひなかつた。御当人の御許しを得ないて紙上に靶 せるのは失礼かとも思つたか、敢て盟友諸士に傅えて御 参考供する次第てある。（荒件瓷吉） 